\title{
LDH as a prognostic marker in hypertensive pregnancy
}

\author{
Prathap Talwar*, Triveni Kondareddy, Pranidha Shree C. A.
}

Department of Obstetrics and Gynecology, SS Medical College and Hospital, Mysuru, Karnataka, India

Received: 24 March 2017

Accepted: 22 April 2017

\section{*Correspondence: \\ Dr. Prathap Talwar, \\ E-mail: drprathapt@gmail.com}

Copyright: (c) the author(s), publisher and licensee Medip Academy. This is an open-access article distributed under the terms of the Creative Commons Attribution Non-Commercial License, which permits unrestricted non-commercial use, distribution, and reproduction in any medium, provided the original work is properly cited.

\begin{abstract}
Background: Pregnancy induced hypertension $(\mathrm{PIH})$ is a global problem with a $5-15 \%$ incidence rate in India and complicating 10-17\% of all pregnancies. These are multisystem disorders and lead to a lot of cellular death. LDH is an intracellular enzyme and its level is increased in these women due to cellular death. So, serum LDH levels can be used to assess the extent of cellular death and thereby the severity of disease in this group of women. The objective of the study was to correlate the severity of the disease, maternal and perinatal outcome with Lactic Dehydrogenase (LDH) levels in serum in patients of preeclampsia and eclampsia.

Methods: A prospective comparative study was conducted in the department of Obstetrics and Gynecology, JSS Medical Hospital, Mysore.

Results: LDH levels were significantly elevated in women with preeclampsia and eclampsia $(<0.001)$. Higher LDH levels had significant correlation with high blood pressure $(\mathrm{P}<0.10)$ as well as poor maternal and perinatal outcome.

Conclusions: High serum LDH levels correlate well with the severity of the disease and poor outcomes in patients of preeclampsia and eclampsia.
\end{abstract}

Keywords: Eclampsia, prognosis, Lactic Dehydrogenase, Preeclampsia

\section{INTRODUCTION}

Preeclampsia is a multisystem disorder that complicates $5-15 \%$ of pregnancies in India. ${ }^{1}$ Pre-eclampsia is one of the leading causes of maternal and fetal morbidity and mortality. ${ }^{2}$ Preeclampsia is a multisystem disorders and lead to a lot of cellular death. LDH is an intracellular enzyme and its level is increased in these women due to cellular death.

So, serum LDH levels can be used to assess the extent of cellular death and thereby the severity of disease. ${ }^{3}$ Nevertheless, the accurate identification of women at risk, early diagnosis, and prompt and appropriate management may help to improve maternal outcome, and possibly perinatal outcome, as well. Currently, there are no clinically available tests that perform well in distinguishing women who will develop preeclampsia from those who will not. ${ }^{4}$ The aim of the present study was to compare serum LDH levels in normal pregnant women and in women with preeclampsia and eclampsia.

The objective of the study was to compare serum $\mathrm{LDH}$ levels in the normal pregnant women and in women with preeclampsia and eclampsia in ante-partum period.

\section{METHODS}

This was a prospective comparative study conducted in the department of Obstetrics and Gynaecology in JSS Hospital, Mysore for 2 years. Pregnant women were enrolled in this study are divided into following groups:

Group 1: Healthy normal pregnant women (controls). Group 2: Patients of preeclampsia and eclampsia 
(subjects). This was further subdivided into following subgroups

- Mild preeclampsia

- Severe preeclampsia

- Eclampsia

Subjects were also divided according to the serum LDH levels into following groups:

- $<600 \mathrm{IU} / 1$

- 600-800 IU/1

- $>800 \mathrm{IU} / \mathrm{l}$
All women were followed until delivery and early postpartum period and babies till early neonatal period.

\section{RESULTS}

Total 180 patients were studied, of which 50 were normal pregnant women; 50 were mild preeclampsia, 50 were severe preeclampsia and 30 cases were of eclampsia. The maximum number of patients in control group as well as study group belonged to the age group of 21-25 years. When compared statistically, the age wise distribution in the subjects was almost similar to the control group.

Table 1: Raised LDH cases.

\begin{tabular}{|lllll|}
\hline Mean LDH & Normotensive (controls) & Mild & Severe & Eclampsia \\
\hline $\begin{array}{l}\text { No. of raised } \\
\text { LDH cases }\end{array}$ & $0 / 50(-)$ & $413.7000 \pm 61.5534$ & $565.8800 \pm 60.0182 \downarrow^{* *}$ & $863.6000 \pm 287.4130 \downarrow^{* *}$ \\
\hline
\end{tabular}

In the present study, the LDH levels were significantly raised with the severity of the disease $(\mathrm{P}<0.001)$. Serum LDH showed $(863.6000 \pm 287.41)$ significantly higher levels in eclamptic women in comparison to mild $\mathrm{PIH}$ (413.7000 \pm 61.55$)$, severe PIH $(565.8800 \pm 60.0182)$ and normotensive group $(191.5000 \pm 23.53)(\mathrm{P}<0.001)$.

Table 1 shows, as severity of disease increases the number of raised LDH cases.

\section{DISCUSSION}

In the present study, LDH has been evaluated as a biochemical marker for preeclampsia and eclampsia. The mean LDH levels in normal controls was $299 \pm 79$ IU/l, in patients with mild preeclampsia was $348 \pm 76 \mathrm{IU} / 1$ and in patients with severe preeclampsia was $774 \pm 69.61 \mathrm{IU} / 1$ was found in Qublan et al. ${ }^{3}$ Thus, they demonstrated a significant association of serum LDH levels with severe preeclampsia $(\mathrm{P}<=0.001)$.

In the present study. the LDH levels were significantly raised with the severity of the disease $(P<=0.001)$ and this was in accordance with the above study.
In another study by Jaiswar SP et al. ${ }^{5}$ the control arm had mean LDH levels of $278.3 \pm 119.2$ IU/1 (normotensives). In mild preeclampsia group, it was $400.45+145.21 \mathrm{IU} / 1$, in severe preeclampsia group it was $646.95 \pm 401.64 \mathrm{IU} / \mathrm{l}$ and eclampsia group was $1648.10 \pm 1992.29$ IU/1. Jaiswer $\mathrm{SP}$, et al. ${ }^{5}$ also demonstrated a significant rise in the LDH levels with increasing severity of the disease $(\mathrm{P}<0.001)$.

In the present study, significantly higher serum LDH level was observed in preeclamptic women than normotensive pregnant women. These results are similar to other authors. ${ }^{6-8}$ Literature review suggested that in the progressive endothelial dysfunction in maternal vascular system induced by toxins released from hypoxic placenta cause profound vasoconstriction affecting all organ system including liver. This hypoperfusion induced ischaemic injury to hepatic cells and other organs cause increased release of intracellular LDH to circulation. ${ }^{9-17}$ In the present study, increased serum LDH level in preeclamptic women than control women are attributed to these facts. Moreover, the progressively increased LDH level in severe preeclampsia indicates progression of cellular injury with severity of this disorder.

Table 2: LDH levels in relation to severity of hypertension in pregnancy.

\begin{tabular}{|lllll|} 
Authors & Control (IU/L) & $\begin{array}{l}\text { Mild Pre-eclampsia } \\
\text { (IU/L) }\end{array}$ & $\begin{array}{l}\text { Severe pre-eclampsia } \\
\text { (IU/L) }\end{array}$ & Eclampsia (IU/L) \\
\hline Qublan et al. & $299 \pm 79$ & $348 \pm 76$ & $774 \pm 69.61 \downarrow^{* *}$ & - \\
\hline Jaiswer SP, et al. & $278.3 \pm 119.2$ & $400.45+145.21$ & $646.95 \pm 401.64 \downarrow^{* *}$ & $1648.10 \pm 1992.29 \downarrow^{* *}$ \\
\hline Present study. & $191.5 \pm 23.53$ & $413.7 \pm 61.5$ & $565.88 \pm 60.81 \downarrow^{* *}$ & $863.60 \pm 287.41 \downarrow^{* *}$ \\
\hline
\end{tabular}




\section{CONCLUSION}

Serum LDH is the earliest marker seen in blood during hypoxia and oxidative stress. It is raised in cases of Preeclampsia and Eclampsia. It is a useful biochemical marker as it reflects the severity of and the occurrence of complications of Preeclampsia and Eclampsia; these are preventable if identified at an earlier stage and adequately managed at a higher center. The test is easily available. Detection of high-risk patients with increased levels of LDH mandates close monitoring, prompt and correct management to decrease both maternal and fetal morbidity and mortality. Therefore, we conclude from this study that screening of all cases of Preeclampsia and Eclampsia with LDH levels should be made mandatory.

Funding: No funding sources Conflict of interest: None declared

Ethical approval: The study was approved by the Institutional Ethics Committee

\section{REFERENCES}

1. Mackey AP, Berg CJ, Atrash HK. Pregnancy related mortality from preeclampsia and eclampsia. Am J Obstet Gynecol. 2001;97(4):533-8.

2. Shah MR. Hypertensive disorders in pregnancy. $1^{\text {st }}$ edn published by Jaypee. 2007:1-10.

3. Qublan HS, Amarun V, Bateinen O, Al-Shraideh Z, Tahat Y, Awamleh I, et al. LDH as biochemical marker of adverse pregnancy outcome in severe preeclampsia. Med Sci Monit. 2005;11:393-7.

4. Pennington KA, Schlitt JM, Jackson DL, Schulz LC, Schust DJ. Preeclampsia: multiple approaches for a multifactorial disease. Dis Model Mech. 2012;5(1):918. stet Gynecol. 2001;97(4):533-8.

5. Jaiswar SP, Gupta A, Rekha S, Natu SN, Shaili Mohan. Lactic Dehydrogenase: A biochemical marker for preeclampsia-eclampsia. JOGI, 2011; 61(6):645-8.

6. Sarkar PD, Sogani S. Evaluation of serum lactate dehydrogenase and gamma glutamyl transferase in preeclamptic pregnancy and its comparison with normal pregnancy in third trimester. Int J Res Med Sci. 2013;1(4):365-8.
7. Aziz R, Mahboob T. Relation between preeclampsia and cardiac enzymes. ARYA Atheroscler J. 2008; 4(1):29-32.

8. Al-Jameil N, Tabassum H, Al-Mayouf H, Al-Otay L, Khan FA. Liver function tests as probable markers of preeclampsia-A prospective study conducted in Riyadh. JCAM. 2013:1-4.

9. Munde SM, Hazari NR, Thorat AP, Gaikwad SB, Hatolkar VS. Gamma glutamyl transferase and Lactate dehydrogenase as biochemical markers of severity of preeclampsia. Int J Med Health Pharm Biomed Eng. 2014;8(1):50-3.

10. Wagner LK. Diagnosis and management of preeclampsia. Am Fam Physician. 2004;70(12): 2317-24.

11. Bera S, Gupta S, Roy SS, Kunti S, Biswas S, Ghosh D. Study of liver enzymes especially lactateinduced hypertension. Sch J App Med Sci. 2014;2(5A):156972.

12. Staff AC, Benton SJ, Dadelszen PV, Roberts JM, Taylor RN, Powers RWD. et al. Redefinining preeclampsia using placenta-derived biomarkers. Hypertens. 2013;61:932-42.

13. Var A, Yildirim Y, Onur E, Kuscu NK, Uyanik BS, Goktalay K, et al. Endothelial dysfunction in preeclampsia. Gynecol Obstet Invest. 2003;56:221-4.

14. Petla LT, Chikkala R, Ratnakar KS, Kodati V, Sritharan V. Biomarkers for the management of preeclampsia in pregnant women. Indian J Med Res. 2013;138:60-7.

15. Dutta DC. Text Book of Obstetrics. 6th ed. Calcutta: New Central Book Agency (P) Ltd; 2008:666.

16. Sonagra AD, Dattatreya K, Murthy JDS. Serum LDH, ALP and Uric Acid in hypertensive disorders of pregnancy. IJPBS. 2012;2(3):201-9.

17. Kozic JR, Benton SJ, Hutcheon JA, Payne BA, Magee LA, Dadelszen PV. Abnormal liver function tests as predictors of adverse maternal outcomes in women with preeclampsia. JOGC. 2011;33(10): 9951004.

Cite this article as: Talwar $\mathrm{P}$, Kondareddy $\mathrm{T}$, Pranidha SCA. LDH as a prognostic marker in hypertensive pregnancy. Int J Reprod Contracept Obstet Gynecol 2017;6:2444-6. 